\title{
Protein requirements for growth in male and female Saanen goats
}

\author{
Amélia Katiane de Almeida ${ }^{1}$, Kléber Tomás de Resende ${ }^{1}$, Simone Pedro da Silva ${ }^{2}$, Diogo da \\ Costa Soares' ${ }^{1}$, Márcia Helena Machado da Rocha Fernandes', Izabelle Auxiliadora Molina de \\ Almeida Teixeira ${ }^{1}$
}

\author{
${ }^{1}$ Universidade Estadual Paulista, Faculdade de Ciências Agrárias e Veterinárias, Jaboticabal, SP, Brasil. \\ 2 Instituto Federal Goiano, Hidrolândia, GO, Brasil.
}

\begin{abstract}
The objective of this study was to determine the protein requirements for the growth of intact male, female, and castrated male Saanen goats weighing 30 to $45 \mathrm{~kg}$ of body weight (BW) and to compare estimates of the protein requirements for maintenance $\left(\mathrm{NP}_{\mathrm{m}}\right)$ by the comparative slaughter and nitrogen balance techniques. To determine the maintenance requirements, 55 goats were assigned in a split-plot design using a $3 \times 3$ factorial arrangement (three sexes and three dry matter intake (DMI) levels). A linear regression of retained N (as measured by the slaughter technique and estimated from the nitrogen balance) on $\mathrm{N}$ intake on a daily basis was used to calculate the net protein for maintenance. The net protein requirement for weight gain $\left(\mathrm{NP}_{\mathrm{g}}\right)$ was obtained using 65 goats fed ad libitum in a completely randomized design. The first derivative of the allometric equation of protein content in the empty BW with respect to the empty BW yielded estimates of the NP. According to the comparative slaughter technique, the estimated $\mathrm{NP}_{\mathrm{m}}$ was $1.46 \mathrm{~g} / \mathrm{kg}$ of metabolic weight, which is $50 \%$ lower than the estimate from the nitrogen balance technique. When evaluating the variance of the error, the nitrogen balance also showed greater values, indicating less precision compared with that of the comparative slaughter technique. The daily $\mathrm{NP}_{\mathrm{g}}$ ranged from $155.7 \pm 10.9$ to $153.4 \pm 13.5 \mathrm{~g} / \mathrm{kg}$ of EBW gain for growing Saanen goats. The protein requirements $\left(\mathrm{NP}_{\mathrm{m}}\right.$ and $\left.\mathrm{NP}_{\mathrm{g}}\right)$ of intact male, female, and castrated male Saanen goats are similar, from 30 to $45 \mathrm{~kg} \mathrm{BW}$, in accordance with current feeding systems. Moreover, the results of the present study indicate that the estimate of $\mathrm{NP}_{\mathrm{m}}$ using the comparative slaughter technique is more precise and lower than that using the $\mathrm{N}$ balance technique.
\end{abstract}

Key Words: comparative slaughter, dairy, factorial approach, maintenance, nitrogen balance

\section{Introduction}

To ensure goat production profitability, precise information regarding their protein requirements is necessary to ensure an adequate supply of this nutrient to prevent losses of nitrogen to the environment. The determination of protein requirements is particularly complex given that nitrogen metabolism in ruminants and for growing goats can be split into maintenance and gain. In addition, the potential effects of sex protein requirements have not been well defined for goats in current feeding systems (NRC, 2007; CSIRO, 2007; AFRC, 1998). The determination of the net protein requirements for maintenance is crucial, corresponding to unavoidable losses of nitrogen via urine, feces, and skin multiplied by a factor of 6.25. These protein losses occur in digestion processes due to an inefficient retention of absorbed amino acids and

Received May 18, 2015 and accepted July 29, 2015

Corresponding author: kresende@fcav.unesp.br

http://dx.doi.org/10.1590/S1806-92902015001100004

Copyright (C) 2015 Sociedade Brasileira de Zootecnia. This is an Open Access article distributed under the terms of the Creative Commons Attribution License (http://creativecommons.org/licenses/by/4.0/), which permits unrestricted use, distribution, and reproduction in any medium, provided the original work is properly cited. the use of absorbed amino acids as a source of energy rather than protein synthesis (Tamminga et al., 1995).

The net protein requirements for maintenance can be estimated by measuring the losses directly, measuring them in a metabolism trial, estimating protein retention by nitrogen balance or measuring the nitrogen that is retained in the body by the comparative slaughter technique, which is laborious and time consuming. In addition, the $\mathrm{N}$ balance is a better conceptual representation of the protein requirements for maintenance. It is based on a few days of measurements during a metabolism trial; consequently, it may be affected by any condition during this specific period (Forbes, 1973; Hegsted, 1976), jeopardizing results.

The literature has reported variations in nitrogen excretion in feces (Blaxter and Mitchell, 1948; Lobley et al., 2000; Kiran and Mutsvangwa, 2007; Huhtanen et al., 2009; Dias et al., 2011) and urine (Kiran and Mutsvangwa, 2007; Bohnert et al., 2011; Ghassemi Nejad et al., 2014) due to dietary changes and environmental conditions. The circumstances causing this phenomenon are poorly understood (O'Brien et al., 2010; Bernabucci et al., 2010; Mahjoubi et al., 2014). Therefore, in this study, we aimed to determine the protein requirements for the growth of intact male, female, and castrated male Saanen goats weighing 
30 to $45 \mathrm{~kg}$ of body weight and to compare the estimates of protein requirements for maintenance by the comparative slaughter and nitrogen balance techniques.

\section{Material and Methods}

The study was conducted in Jaboticabal, São Paulo State, Brazil (21 $1^{\circ} 14^{\prime} 05^{\prime \prime S}$ and $48^{\circ} 17^{\prime} 09^{\prime \prime} \mathrm{W}$, altitude $\left.595 \mathrm{~m}\right)$, from August 2010 to June 2011. The average minimum, maximum, and mean daily temperatures during this period were 17,29 , and $22.4{ }^{\circ} \mathrm{C}$, respectively, and the average minimum, maximum, and mean daily humidity were 88,41 , and $67 \%$, respectively. Humane animal care and handling procedures were followed in accordance with the Animal Care Committee on Ethical and Animal Welfare (Comissão de Ética e Bem Estar Animal - CEBEA) of UNESP, under protocol \#004972-09.

The factorial approach was used to estimate the protein requirements, and the net requirements for maintenance and gain were estimated separately. Two trials were conducted using castrated male, intact male, and female Saanen goats. The first trial was designed to determine the net protein requirements for maintenance $\left(\mathrm{NP}_{\mathrm{m}}\right)$, while the second trial was designed to estimate the net protein requirements for gain $\left(\mathrm{NP}_{\mathrm{g}}\right)$.

In both trials, the experimental diet (Table 1) consisted of dehydrated whole corn plants (prepared as described by Bompadre et al., 2014), cracked corn grain, soybean meal, soybean oil, limestone, and a mineral supplement, which were fed as a total mixed ration at 46.2, 30.9, $15.2,1.9,1.0$, and $4.8 \%$ of dry matter (DM), respectively. The feed ingredients were dried at $55{ }^{\circ} \mathrm{C}$ for $72 \mathrm{~h}$, ground through a 1-mm screen using a Wiley mill (Arthur $\mathrm{H}$. Thomas Co., Philadelphia, PA), and analyzed for ash (complete combustion in a muffle furnace at $600{ }^{\circ} \mathrm{C}$ for $6 \mathrm{~h}$; AOAC, 2005; method number 942.05), fat (method 920.39; AOAC, 2005), protein (N analysis performed via Dumas combustion using LECO FP-528LC, LECO Corp., St. Joseph, MI; AOAC, 2005; method number 992.15), neutral detergent fiber (NDF) with amylase and without sulfite, acid detergent fiber (ADF) (AOAC, 2005; method 973.18), and gross energy (GE) using a bomb calorimeter $\left(\right.$ IKA $^{\circledR}$ Calorimeter system C 2000 basic/control, IKA-Works, Cincinnati, USA).

To determine the $\mathrm{NP}_{\mathrm{m}}, 55$ goats were used: 18 intact males $(30.3 \pm 0.88 \mathrm{~kg}$ of body weight, BW), 21 castrated males $(30.2 \pm 0.73 \mathrm{~kg}$ of initial $\mathrm{BW})$, and 16 females $(29.9 \pm 0.34 \mathrm{~kg}$ of initial BW). These animals were pairfed in slaughter groups: six and seven complete groups of intact males and castrated males, respectively, and six incomplete groups of females. One female from slaughter group 4 and another from slaughter group 5 under different treatments were removed during the experiment due to sickness, resulting in an unbalanced split-plot design in a $3 \times 3$ factorial arrangement, with three sexes (intact males, castrated males, and females) and three levels of intake: ad libitum and $75 \%$ or $50 \%$ of the ad libitum intake. The animals were fed twice a day (07.00 and $16.00 \mathrm{~h})$; the intake of the animals that were fed ad libitum was adjusted to allow for $20 \%$ daily leftovers, while the animals that were subjected to the levels of $75 \%$ and $50 \%$ of intake would have their intake based on the amount that was consumed by the animals that were fed ad libitum in the same slaughter group. A slaughter group included one animal from each treatment, and slaughter occurred when the animal under ad libitum feeding reached $45 \mathrm{~kg}$ of BW; the same number of days (d) in the experiment was applied to the animals that were subjected to $75 \%$ and $50 \%$ of intake.

The initial empty body composition was estimated from the composition of the animals that were slaughtered at the beginning of the trial, which was denominated as baseline group. For the baseline groups, we used nine randomly selected castrated males, with $30.6 \pm 1.46 \mathrm{~kg}$ of BW and an initial age of $274 \pm 31$ d; eight randomly selected

Table 1 - Ingredient and chemical composition of the diet

\begin{tabular}{|c|c|c|c|c|c|c|c|}
\hline \multirow{2}{*}{ Ingredient } & \multirow{2}{*}{$\begin{array}{c}\mathrm{DM} \\
(\mathrm{g} / \mathrm{kg} \text { as-fed) }\end{array}$} & \multicolumn{6}{|c|}{ Ingredients composition ( $\mathrm{g} / \mathrm{kg}$ of $\mathrm{DM})$} \\
\hline & & $\mathrm{OM}$ & $\mathrm{CP}$ & $\mathrm{EE}$ & NDF & $\mathrm{NFC}$ & $\mathrm{GE}^{1}$ \\
\hline Dehydrated corn plant & 850 & 960 & 85 & 16 & 568 & 290 & 19.2 \\
\hline Soybean meal & 861 & 931 & 542 & 22 & 158 & 216.1 & 20.3 \\
\hline Cracked corn grain & 858 & 989 & 85 & 47 & 127 & 728 & 19.2 \\
\hline Soybean oil & 995 & 997 & - & 991 & - & - & 38.6 \\
\hline Limestone & 999 & 3 & - & - & - & - & - \\
\hline Mineral supplement ${ }^{2}$ & 969 & 56 & - & - & - & - & - \\
\hline Total mixed ration & 866 & 907 & 147 & 48 & 312 & 391 & 18.5 \\
\hline
\end{tabular}

DM - dry matter; OM - organic matter; CP - crude protein; EE - ether extract; NDF - neutral detergent fiber; NFC - non-fibrous carbohydrates.

${ }^{1} \mathrm{GE}$ - gross energy ( $\mathrm{MJ} / \mathrm{kg}$ of $\left.\mathrm{DM}\right)$.

${ }^{2}$ Composition, per kg, as-fed basis: $190 \mathrm{~g}$ of Ca; $92 \mathrm{~g}$ of Cl; $73 \mathrm{~g}$ of P; $62 \mathrm{~g}$ of Na; $44 \mathrm{~g}$ of Mg; $1.35 \mathrm{~g}$ of $\mathrm{Zn} ; 1.06 \mathrm{~g}$ of Fe; $0.94 \mathrm{mg}$ of Mn; $0.73 \mathrm{~g}$ of F (maximum); $0.34 \mathrm{~g}$ of Cu; $18 \mathrm{mg}$ of Se; $16 \mathrm{mg}$ of I; and $3 \mathrm{mg}$ of Co. 
intact males that were slaughtered at $31.1 \pm 1.81 \mathrm{~kg}$ of BW and an initial age of $281 \pm 33 \mathrm{~d}$; and 13 randomly selected females that were slaughtered at $29.8 \pm 1.34 \mathrm{~kg}$ of BW and an initial age of $283 \pm 33$ d. Simple regression equations were developed from the baseline groups to determine the initial empty BW (EBW; $\mathrm{kg}$ ) from the body weight and the initial empty body energy (MJ) from the EBW. The estimate of the initial body composition was crucial to estimate the retained $\mathrm{N}$ and protein in the body during the studied phase. The baseline group represented the body composition of the animals that were slaughtered at the end of the Trial 1, all for the estimation of the $\mathrm{N}$ and protein retention.

When the animals that were fed ad libitum reached $38.3 \pm 0.71 \mathrm{~kg}$ of BW, a metabolism trial was conducted (from December 2010 to February 2011). All of the animals were housed in individual metabolic cages. The feed supplied, orts, feces, and urine were collected for $5 \mathrm{~d}$ after a 3-d period of adaptation to the cage. Urine was acidified daily with $20 \mathrm{~mL}$ of $20 \%$ sulfuric acid (v/v). The feeds and orts were sampled daily, and the samples were stored at $-20{ }^{\circ} \mathrm{C}$. The total feces and urine were weighed daily, and a $10 \%$ sample was collected and stored at $-20{ }^{\circ} \mathrm{C}$. Composite samples of feeds, orts, and feces were dried at $55^{\circ} \mathrm{C}$ for $72 \mathrm{~h}$ and ground through a 1-mm screen using a Wiley mill. Composite samples of urine were passed through a sieve and sub-sampled for nitrogen content determination. The nitrogen content was determined for the feeds, orts, feces, and urine via Dumas combustion using LECO FP-528LC (LECO Corp., St. Joseph, MI).

The BW was measured immediately before slaughter. At slaughter, the animals were stunned with a captive bolt pistol, followed by severing of the jugular vein and carotid artery. Blood was collected and weighed. The digestive tract was weighed before and after it was emptied and flushed with water. The EBW was calculated as the BW at slaughter minus the weight of the contents of the digestive tract, gallbladder, and biliary vesicle. The empty whole body was initially frozen at $-6{ }^{\circ} \mathrm{C}$ and then cut into small pieces, ground with a large screw grinder through a plate with $0.32-\mathrm{cm}$ holes, and mixed by two additional passes through the grinder. After grinding and homogenization, the samples were collected and frozen again, and subsamples were freeze-dried for DM determination. These samples, which were of approximately $30 \mathrm{~g}$, were analyzed for protein as described previously.

A linear regression of retained $\mathrm{N}$ ( $\mathrm{g}$ of $\mathrm{N} \mathrm{kg} \mathrm{kg}^{0.75} / \mathrm{BW}$ ) on $\mathrm{N}$ intake ( $\mathrm{g}$ of $\mathrm{N} \mathrm{kg}{ }^{0.75} / \mathrm{BW}$ ) was used to calculate the $\mathrm{NP}_{\mathrm{m}}$ on a daily basis. The intercept of the regression was assumed to be the endogenous and metabolic losses of $\mathrm{N}$, which are assumed to represent the net $\mathrm{N}$ requirement for maintenance. This value multiplied by a factor of 6.25 provided the estimates of $\mathrm{NP}_{\mathrm{m}}$. This procedure was performed with the comparative slaughter and nitrogen balance techniques.

The $\mathrm{NP}_{\mathrm{g}}$ was obtained using 65 goats (20 intact males, 22 castrated males, and 23 females) in a completely randomized design. The animals were fed ad libitum twice a day at 07.00 and $16.00 \mathrm{~h}$ and were slaughtered at $30.7 \pm 1.8$ of body weight (nine castrated males, eight intact males, and 13 females) and $38.1 \pm 0.49 \mathrm{~kg}$ of body weight (six intact males, six castrated males, and five females) to represent an intermediary body composition. The remaining goats were slaughtered when they reached $44.0 \pm 0.5 \mathrm{~kg}$ of BW (six intact males, seven castrated males, and five females). During this growth phase, the average daily gain of these animals ranged from 56 to $259 \mathrm{~g} / \mathrm{d}$. The slaughter procedures and laboratory analyses were similar to those previously described. Allometric equations (Eq. [1]) were used to predict the protein content from EBW $(\mathrm{kg})$ as follows:

$$
\text { Protein }=\alpha \times E B W^{\beta} \times e
$$

in which Protein $=$ total amount of protein in the EBW (g); $E B W=$ empty body weight $(\mathrm{kg}) ; \alpha$ and $\beta=$ regression parameters; and $e=$ residual.

The first derivative of Protein with respect to EBW yielded estimates of the $\mathrm{NP}_{\mathrm{g}}$ at various EBW (Eq. [2]):

$$
N P_{g}=\beta \times \alpha \times E B W^{(\beta-1)}
$$

in which $N P_{g}=$ concentration $(\mathrm{g} / \mathrm{kg})$ per unit of EBW gain (EWG, $\mathrm{kg}$ ); and $\alpha$ and $\beta=$ parameters that were determined from the linear regression (Eq. [1]).

Data from the maintenance trial were analyzed in a split-plot design using a mixed model with the fixed effects of sex ( $d f=2)$, intake level $(d f=2$,) and their interactions $(\mathrm{df}=4)$, as well as the random effect of group nested within sex $(\mathrm{df}=15)$, according to the model:

$$
\mathrm{Y}_{\mathrm{ij}}=\mu+\mathrm{S}_{\mathrm{i}}+\mathrm{g}_{\mathrm{i}: \mathrm{j}}+\mathrm{L}_{\mathrm{k}}+\mathrm{SL}_{\mathrm{ik}}+\mathrm{e}_{\mathrm{ij}}
$$

in which $Y_{i j}=$ expected outcome for the dependent variable $\mathrm{Y} ; \mu=$ overall mean; $\mathrm{S}_{\mathrm{i}}=$ fixed effect of the $\mathrm{i}$-th sex; $\mathrm{g}=$ random effect of the $\mathrm{j}$-th group within the $\mathrm{i}$-th $\operatorname{sex} ; \mathrm{L}=$ fixed effect of the k-th level of intake; SL = the fixed effect of the interaction between the i-th sex and the k-th level of intake; and $\mathrm{e}_{\mathrm{ij}}=$ random residual error, assumed to be $\simeq \mathrm{N}\left(0, \sigma_{\mathrm{e}}^{2}\right)$. When significantly different $(\mathrm{P}<0.05)$, the treatment means were compared using Fisher's protected LSD.

The allometric equation that was generated with the baseline animals to estimate the initial body protein was fitted jointly for the three sexes studied using the PROC NLIN and the MARQUARDT methods of SAS (Statistical Analysis System; Institute Inc., Cary, NC, version 9.4). This 
statistical analysis tested the effect of sex on the function parameters using a straightforward t-test (Noftsger et al., 2005). The HOUGAARD option of PROC NLIN was used to estimate the skewness of the parameters that were estimated and was also used to ensure that the t-tests were valid.

Data from gain trial were analyzed as a completely randomized design with fixed effects of $\operatorname{sex}(\mathrm{df}=2)$, slaughter body weight $(\mathrm{df}=2)$, and their interactions $(\mathrm{df}=4)$, according to the model:

$$
\mathrm{Y}_{\mathrm{ij}}=\mu+\mathrm{S}_{\mathrm{i}}+\mathrm{W}_{\mathrm{j}}+\mathrm{e}_{\mathrm{ij}}
$$

in which $\mathrm{Y}_{\mathrm{ij}}=$ expected outcome for the dependent variable $\mathrm{Y} ; \mu=$ overall mean (or intercept); $\mathrm{S}_{\mathrm{i}}=$ fixed effect of the $\mathrm{i}$-th sex; $\mathrm{W}_{\mathrm{i}}=$ fixed effect of the $\mathrm{j}$-th slaughter weight; and $\mathrm{e}_{\mathrm{ij}}=$ random residual error, assumed to be $\simeq \mathrm{N}\left(0, \sigma_{\mathrm{e}}^{2}\right)$. The allometric equation parameters were estimated as previously described with the baseline animals for predicting the initial body protein. After parameter estimation, the allometric equation ((Eq. [2]) was associated with the Monte Carlo statistical method (Markov chain), to simulate the first derivative of allometric equation variation, and then net protein requirements for gain variation. For that, mean and standard deviation of parameters estimates, and their correlation were considered to generate the dataset. Bivariate Normal techniques were analyzed using Bivariate 4.6, SAS for Monte Carlo Studies (Fan et al., 2002).

Linear regression analyses from both trials (i.e., the retained $\mathrm{N}$ on $\mathrm{N}$ intake and the $\mathrm{EBW}$ on $\mathrm{BW}$ ) were performed with the MIXED procedure. The allometric equation parameters were evaluated by the CONTRAST option to test values for each sex.

a)

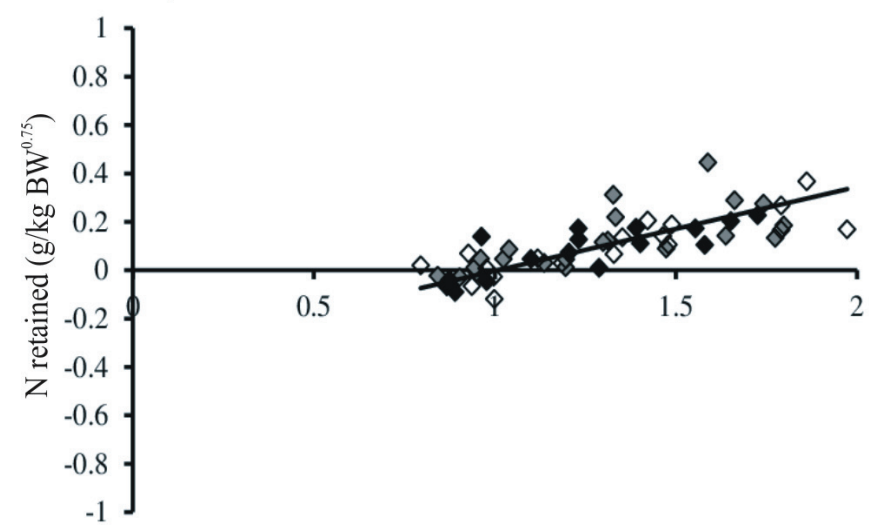

\section{Results}

The initial BW did not differ among the sexes $(\mathrm{P}=0.33)$ in the maintenance trial. During the metabolism trial, the animals showed a mean dry matter intake (DMI) that was very similar to the value found when the entire experiment was evaluated $(767.1 \mathrm{~g} / \mathrm{d}$ vs. $731.8 \mathrm{~g} / \mathrm{d})$. During the metabolism trial, the BW, DMI, and N intake decreased as the level of intake decreased (Table 2). We also detected the effect of sex on metabolic BW; intact males were heavier than were castrated males and females during the metabolism trial (means, $14.2 \mathrm{vs.} 13.8 \mathrm{~kg}$ ). The digestibility of DM and protein decreased at decreasing rates as the intake level increased; however, sex did not affect nutrient digestibility.

A linear relationship was found between $\mathrm{N}$ intake and the $\mathrm{N}$ retained in the body for both of the tested techniques (Table 2). Not surprisingly, the $\mathrm{N}$ intake and fecal $\mathrm{N}$ followed the same pattern as DMI (Table 2). In addition, the urinary $\mathrm{N}$ was not affected by intake level and therefore was not a response of $\mathrm{N}$ intake. As a result, the nitrogen balance decreased linearly as the level of intake increased, in all evaluated sexes.

The results of $\mathrm{NP}_{\mathrm{m}}$ did not show differences among the sexes $(\mathrm{P}>0.05)$ (Figure 1). Using the comparative slaughter technique, the estimated $\mathrm{N}$ losses were $234 \mathrm{mg}$ of $\mathrm{N} / \mathrm{kg}$ of $\mathrm{BW}^{0.75}$ (at $\mathrm{N}$ intake $=0$ ), which corresponds to an $\mathrm{NP}_{\mathrm{m}}$ equal to $1.46 \mathrm{~g} / \mathrm{kg}$ of $\mathrm{BW}^{0.75}$.

No difference was detected in average daily gain among the sexes $(\mathrm{P}>0.05$; mean of $135 \pm 0.037)$. The parameters of

b)

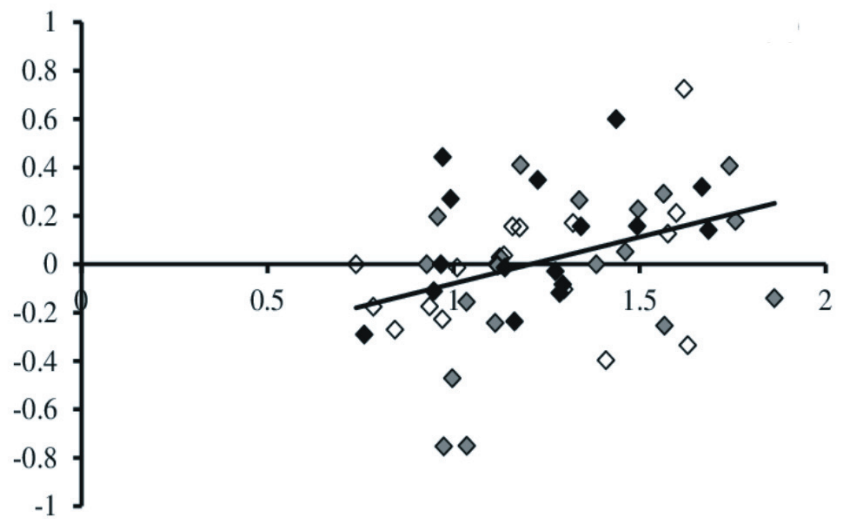

$\mathrm{N}$ intake $\left(\mathrm{g} / \mathrm{kg} \mathrm{BW}^{0.75}\right)$

$\diamond$ represents observations of intact males, $\downarrow$ females, and $\downarrow$ castrated males.

Figure 1 - Relationship between the daily $\mathrm{N}$ retained $\left(\mathrm{g} / \mathrm{kg} \mathrm{BW}^{0.75}\right)$ and the daily $\mathrm{N}$ intake $\left(\mathrm{g} / \mathrm{kg} \mathrm{BW}^{0.75}\right)$ using data from the comparative slaughter technique $\left[(\mathrm{a}) ; \mathrm{N}\right.$ retained $=-0.234( \pm 0.0480)+0.281( \pm 0.0331) \times \mathrm{N}$ intake; $\left.\mathrm{P}<0.001 ; \sigma_{\mathrm{e}}^{2}=0.00551 ; \sigma_{\mathrm{b}}^{2}=0.00108\right]$ or nitrogen balance technique $\left[(b) ; \mathrm{N}\right.$ retained $=-0.5417( \pm 0.1973)+0.4409( \pm 0.1531) \times \mathrm{N}$ intake; $\mathrm{P}=0.0063 ; \sigma^{2}=0.0828$; $\left.\sigma_{\mathrm{b}}^{2}=0.00115\right]$ of growing Saanen goats of different sexes. 


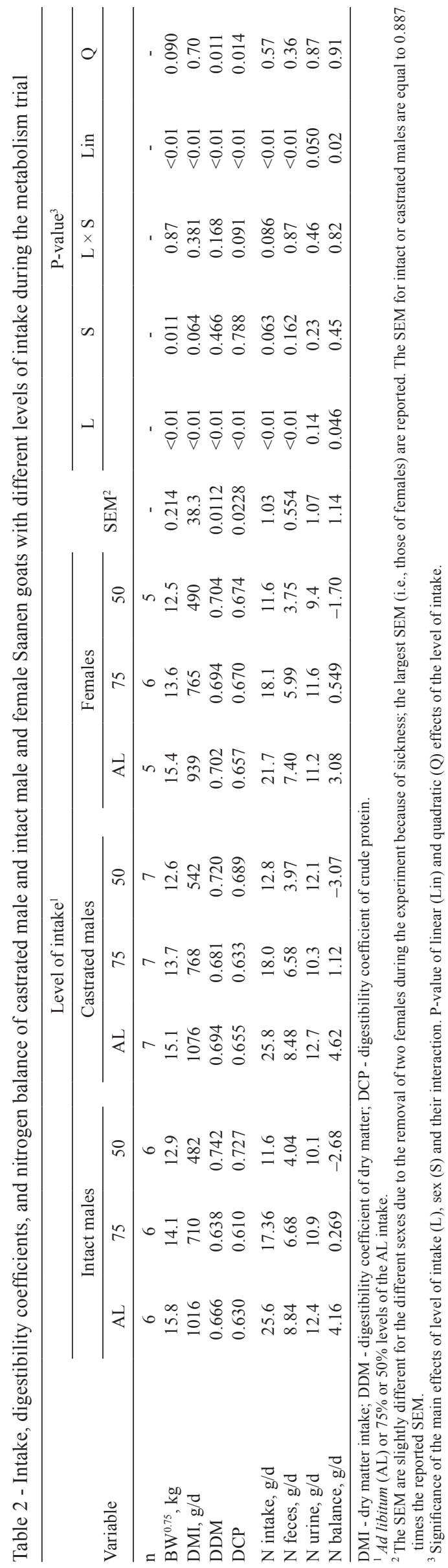

the allometric equations to predict the protein concentration from the EBW did not differ between sexes; therefore, a general equation (Eq. [3], $\mathrm{P}<0.0001, \sigma^{2}=189179$ ) is proposed. Because Eq. [3] depends on the relationship between $\mathrm{BW}$ and $\mathrm{EBW}$, this regression equation was also estimated: Eq. [4] $\left(\mathrm{P}<0.0001 ; \sigma_{\mathrm{e}}^{2}=0.968\right)$

$$
\begin{gathered}
\text { Protein }=188.8( \pm 48.3) \times E B W^{0.963( \pm 0.0728)} \\
E B W=-3.78( \pm 0.981)+0.934( \pm 0.0251) \times B W
\end{gathered}
$$

in which Protein = body protein $(\mathrm{g}) ; E B W=$ empty body weight $(\mathrm{kg})$; and $B W=$ body weight $(\mathrm{kg})$.

Using the first derivative of Eq. [3] with respect to EBW, the yielded estimate of the net protein requirements for growth is presented in Eq. [5]. No effects of sex were observed on the rate of EBW protein accretion between 30 and $45 \mathrm{~kg}$ of BW in Saanen goats. The daily $\mathrm{NP}_{\mathrm{g}}$ ranged from $155.7 \pm 10.9$ to $153.4 \pm 13.5 \mathrm{~g} / \mathrm{kg}$ of EBW gain (132.4 to $130.4 \mathrm{~g} / \mathrm{kg}$ of BW gain) as the body weight increased from 30 to $45 \mathrm{~kg}$ of BW for growing Saanen goats.

$$
N P_{g}=181.8 \times E B W^{-0.037}
$$

in which $N P_{g}=$ protein concentration $(\mathrm{g} / \mathrm{kg})$ per unit of EBW gain; and $E B W=$ empty body weight $(\mathrm{kg})$.

\section{Discussion}

The observed depressions in the DM and CP digestibility as the level of intake decreased were observed in ruminant species in a previous study (Dias et al., 2011). However, in a meta-analysis published by Huhtanen et al. (2009), it was shown that the effect of the feeding level on digestibility is not always consistent; it depends on the dietary chemical and physical characteristics. Associative effects between dietary components and the feeding level should affect the ruminal retention time and thus the digestibility.

In the present study, the excretion of $\mathrm{N}$ in the feces was positively related to $\mathrm{N}$ ingestion and DMI. In fact, NRC (2007) assumes that $2.67 \%$ of the DMI appears in feces as crude protein, ratifying the existing relationship between $\mathrm{N}$ intake and fecal $\mathrm{N}$. According to our results, the fecal protein was $5 \%$ of the DMI for all sexes. This difference may be explained by differences in the diet characteristics because the NRC (2007) reported a DM digestibility coefficient of 0.88 , which is greater than that found here. In addition, Lobley et al. (2000) and Kiran and Mutsvangwa (2007) reported greater values of nitrogen in feces, approximately $4 \%$ of the DMI. This fact raises the hypothesis that the relationship between DMI and fecal crude protein or nitrogen may be different for animals under different conditions. Indeed, it has been known for a long time that the relationship between DMI and $\mathrm{N}$ in feces 
is consistent if the similarity among the diet is maintained (Blaxter and Mitchell, 1948). However, this relationship is hard to ensure given the wide range of feeds and by-products that are used in animal nutrition; even traditional feed may change between temperate and tropical conditions. It must also be considered that the difference among roughages around the world is enormous (Robinson et al., 2006; Bohnert et al., 2011) and may vary in fiber characteristics and content. Fiber characteristics are very important in this context; for example, tropical feedstuffs, because of a greater content of ADF, can increase undigested N (NIDA) in feces (Bohnert et al., 2011). In addition, Tamminga et al. (1995) suggested that the presence of more fibrous feed in the diet may increase the endogenous $\mathrm{N}$ in feces due to saliva, digestive enzymes, and increased bile secretion, and the sloughing of intestinal mucosal cells and mucins in response to the diet.

In the present study, no relationship between the $\mathrm{N}$ excreted in urine and $\mathrm{N}$ intake was found, which disagrees with previous reports by Luo et al. (2004). These authors developed equations to predict $\mathrm{N}$ excretion via urine by $\mathrm{N}$ intake. The endogenous urinary $\mathrm{N}$ is an inevitable loss that originated from an inefficiency of $\mathrm{N}$-containing-compound metabolism that is related to energy metabolism, and thus frequently scaled at metabolic size. Applying this principle, the NRC (2007) estimated the endogenous urinary crude protein to be $1.031 \mathrm{~g} / \mathrm{kg}$ of $\mathrm{BW}^{0.75}$. In the present work, a relationship was found between metabolic body weight and endogenous urinary crude protein that was five times greater than that reported by NRC (2007). This value may appear inconsistent; however, other reports in the literature present similar (Ghassemi Nejad et al., 2014) or even greater values than ours for other small ruminants (Kiran and Mutsvangwa, 2007), raising the hypothesis that the excretion of nitrogen is dependent on metabolic processes through which balance is achieved in response to a dietary change (Waterlow, 1999). Indeed, Bohnert et al. (2011) reported a variation of $\mathrm{N}$ excreted in urine of $400 \%$ depending on dietary manipulation.

Because the period in which the metabolism trial was carried out was dictated by the body weight of the ad libitum animal of each group, this trial occurred during the summer season. This information is particularly important given the results found here, showing greater $\mathrm{N}$ losses in urine. The literature reported changes in the excretion of $\mathrm{N}$ via urine due to heat stress (Obitsu et al., 2011; Bernier et al., 2014). However, the mechanisms that are involved in this phenomenon are unknown (O'Brien et al., 2010; Bernabucci et al., 2010; Mahjoubi et al., 2014; Kamiya et al., 2005). According to Bernanbucci et al. (2010), the origin and regulation of these metabolic changes are unknown. Reviewing studies on the subject, Bernanbucci et al. (2010) reported that alterations in the hormonal profile cause the response to heat stress and are characterized by a decreased secretion of anabolic hormones and increased catabolic hormones (Kamiya et al., 2006), which may explain the greater $\mathrm{N}$ losses via urine.

Ruminants synthesize urea from $\mathrm{N}$, which is apparently more digested than in non-ruminants (Lapierre and Lobley, 2001). According to these authors, the $\mathrm{N}$ that is recycled to the gastrointestinal tract of ruminants can vary from 40 to $80 \%$ of the urea that is produced by the liver. Huntington and Archibeque (2000) reported an even wider range (19 to $96 \%$ ) and attributed such variation to the diet composition, intake, and productive priorities of the animal. The main point to be considered is that urea production, excretion, and recycling to the gut can vary widely. Urea that is excreted in the urine represents 25 to $60 \%$ of the endogenous urea production in ruminants (Obara and Shimbayashi, 1980; Huntington, 1989). Urine is the main medium through which urea is excreted; however, 65 to $76 \%$ of the urea-N that is transferred to the gastrointestinal tract enters the forestomachs (Huntington, 1989), which means that some $\mathrm{N}$ enters the post-ruminal portion of the gastrointestinal tract and may also appear in feces (Dixon and Nolan, 1986).

Although the $\mathrm{N}$ balance is a better conceptual representation of the protein requirements for maintenance, because it is based on a few days of measurements during a metabolism trial, it can be affected by any condition during this specific period, affecting the complexity involved in nitrogen metabolism and generating confounding results. The results of $\mathrm{N}$ balance would overestimate the $\mathrm{NP}_{\mathrm{m}}$ because the $\mathrm{N}$ losses by feces and urine were greater than those reported in the literature. As extensively discussed previously, little is known about how physiological and metabolic processes influences the $\mathrm{N}$ recycling in the body. Using information from the same animals, estimates of $\mathrm{NP}_{\mathrm{m}}$ by the comparative slaughter technique yielded a more precise equation (i.e., lower $\sigma_{\mathrm{e}}^{2}$ and standard deviation of parameter estimates) than those that was originated from nitrogen balance data. For example, the $\sigma^{2}$ from the comparative slaughter technique equation was more than 10 -fold smaller than the $\sigma_{\mathrm{e}}^{2}$ from the nitrogen balance equation, which can be perceived by the dispersion of the points in Figure 1.

The results presented here did not show differences in the $\mathrm{NP}_{\mathrm{m}}$ among the sexes, which is in accordance with current feeding systems (AFRC, 1998; NRC, 2007). Our estimates were 52 and $34 \%$ lower than that recommended by the 
NRC (2007) and AFRC (1998), respectively (assuming an efficiency of protein utilization for maintenance of 1.0), but similar to those of Ferreira et al. (2015) using the comparative slaughter technique $\left(1.39 \mathrm{~g} / \mathrm{kg}^{0.75}\right.$ of BW). Both feeding systems (i.e., AFRC, 1998 and NRC, 2007) use the nitrogen balance data. This fact raises the hypothesis that this technique may overestimate the $\mathrm{NP}_{\mathrm{m}}$; the extent of the overestimate will be highly dependent on several factors, such as environmental conditions, physiological stage, and diet characteristics, during the metabolism trial.

The AFRC (1998) net protein requirements for gain of goats from 30 to $45 \mathrm{~kg}$ vary from 136.4 to $125.9 \mathrm{~g} / \mathrm{kg}$ of BW gain. Our estimates are also similar to those reported by Ferreira et al. (2015), which varied from 140.7 to $135.9 \mathrm{~g} / \mathrm{kg}$ BW gain between 20 and $35 \mathrm{~kg}$ of BW. However, assuming an efficiency of use of metabolizable protein of 0.5 , the NRC (2007) recommends a slightly greater value $(145 \mathrm{~g} / \mathrm{kg}$ of BW gain). The small difference among the aforementioned studies may be due to differences in the degree of maturity of the animals that were used in each study; it is likely that the $\mathrm{NP}_{\mathrm{g}}$ per unit of gain decreases as the animal grows. In addition, some variations reported in previous studies are similar to those found here; the main point to be considered is that no differences among the sexes were found.

To our knowledge, this is the first study determining the effect of sex on the protein requirements of goats from 30 to $45 \mathrm{~kg}$ of BW using the comparative slaughter technique and the nitrogen balance technique, resulting in more adequate estimates of the requirements for protein and reducing the cost of production.

\section{Conclusions}

Sex does not influence the protein requirements (maintenance and gain) of Saanen goats from 30 to $45 \mathrm{~kg}$ of body weight. Moreover, the results of the present study indicate that estimates of net protein for maintenance by the comparative slaughter technique are more precise and lower than those using the nitrogen-balance technique, which should encourage researchers to clarify the mechanisms that are involved in this difference.

\section{Acknowledgments}

Thanks to the São Paulo Research Foundation (FAPESP) for funding this research and for granting the doctorate fellowship (Grants \#2008/58351-5 and 2010/02482-4) and to CAPES for the scholarship awarded to perform an internship at The Ohio State University. The authors are also thankful to Dr. Normand R. St-Pierre from The Ohio State University for the advice regarding the statistics.

\section{References}

AFRC - Agriculture and Food Research Council. 1998. Technical Committee on Responses to Nutrients, Report No. 10. The nutrition of goats. Nutrition Abstracts and Reviews (Series B) 67:42-51.

AOAC - Association of Official Analytical Chemistry. 2005. Official methods of analysis. 18th ed. AOAC International, Gaithersburg, MD, USA.

Bernabucci, U.; Lacetera, N.; Baumgard, L. H.; Rhoads, R. P.; Ronchi, B. and Nardone, A. 2010. Metabolic and hormonal acclimation to heat stress in domesticated ruminants. Animal 4:1167-1183.

Bernier, J. N.; Undi, M.; Ominski, K. H.; Donohoe, G.; Tenuta, M.; Flaten, D.; Plaizier B, J. C. and Wittenberg, K. M. 2014. Nitrogen and phosphorus utilization and excretion by beef cows fed a low quality forage diet supplemented with dried distillers grains with solubles under thermal neutral and prolonged cold conditions. Animal Feed Science and Technology 193:9-20.

Blaxter, K. L. and Mitchell, H. H. 1948. The factorization of the protein requirements of ruminants and of the protein values of feeds, with particular reference to the significance of the metabolic fecal nitrogen. Journal of Animal Science 7:351-372.

Bohnert, D. W.; Delcurto, T.; Clark, A. A.; Merrill, M. L.; Falck, S. J. and Harmon, D. L. 2011. Protein supplementation of ruminants consuming low-quality cool-or warm-season forage: Differences in intake and digestibility. Journal of Animal Science 89:3707-3717.

Bompadre, T. F. V.; Boaventura Neto, O.; Mendonca, A. N.; Souza, S. F.; Oliveira, D.; Fernandes, M. H. M. R.; Harter, C. J.; Almeida, A. K.; Resende, K. T.; Teixeira, I. A. M. A. 2014. Energy requirements in early life are similar for male and female goat kids. AsianAustralasian Journal of Animal Sciences 27:1712-1720.

CSIRO - Commonwealth Scientific and Industrial Research Organization. 2007. Nutrient requirements of domesticated ruminants. CSIRO Publishing, Collingwood, Australia.

Dias, R. S.; Patino, H. O.; López, S.; Prates, E.; Swanson, K. C. and France, J. 2011. Relationships between chewing behavior, digestibility and digesta passage kinetics in steers fed restricted and ad libitum levels of oat hay. Journal of Animal Science 89:1873-1880.

Dixon, R. M. and Nolan, J. V. 1986. Nitrogen and carbon flows between the caecum, blood and rumen in sheep given chopped lucerne (Medicago sativa) hay. British Journal of Nutrition 55:313-332.

Fan, X.; Sivo, S. and Keenan, S. 2002. SAS for Monte Carlo studies: A guide for quantitative researchers. SAS Institute Inc. Cary, NC, USA.

Ferreira, A. C. D.; Yáñez, E. A.; Medeiros, A. N.; Resende, K. T.; Pereira Filho, J. M.; Fernandes, M. H. M. R.; Almeida, A. K. and Teixeira, I. A. M. A. 2015. Protein and energy requirements of castrated male Saanen goats. Small Ruminant Research 123:88-94.

Forbes, G. B. 1973. Another source of error in the metabolic balance method. Nutrition Reviews 31:297-300.

Ghassemi Nejad, J.; Lohakare, J. D.; West, J. W. and Sung, K. I. 2014. Effects of water restriction after feeding during heat stress on nutrient digestibility, nitrogen balance, blood profile and characteristics in Corriedale ewes. Animal Feed Science and Technology 193:1-8.

Hegsted, D. M. 1976. Balance studies. The Journal of Nutrition 106:307-311.

Huhtanen, P.; Rinne, M. and Nousiainen, J. 2009. A meta-analysis of feed digestion in dairy cows. 2. The effects of feeding level 
and diet composition on digestibility. Journal of Dairy Science 92:5031-5042.

Huntington, G. B. 1989. Hepatic urea synthesis and site and rate of urea removal from blood of beef steers fed alfalfa hay or a high concentrate diet. Canadian Journal of Animal Science 69:215-223.

Huntington, G. B. and Archibeque, S. L. 2000. Practical aspects of urea and ammonia metabolism in ruminants. Journal of Animal Science 77:1-11.

Kamiya, M.; Iwama, Y.; Tanaka, M. and Shioya, S. 2005. Effects of high ambient temperature and restricted feed intake on nitrogen utilization for milk production in lactating Holstein cows. Animal Science Journal 76:217-223.

Kamiya, M.; Kamiya, Y.; Tanaka, M.; Oki, T., Nishiba, Y. and Shioya, S. 2006. Effects of high ambient temperature and restricted feed intake on urinary and plasma 3-methylhistidine in lactating Holstein cows. Animal Science Journal 77:201-207.

Kiran, D. and Mutsvangwa, T. 2007. Effects of barley grain processing and dietary ruminally degradable protein on urea nitrogen recycling and nitrogen metabolism in growing lambs. Journal of Animal Science 85:3391-3399.

Lapierre, H. and Lobley, G. E. 2001. Nitrogen recycling in the ruminant: A review. Journal of Dairy Science 84:E223-E236.

Lobley, G. E.; Bremner, D. M. and Zuur, G. 2000. Effects of diet quality on urea fates in sheep as assessed by refined, non-invasive [NN] urea kinetics. British Journal of Nutrition 84:459-468.

Luo, J.; Goetsch, A. L.; Moore, J. E.; Johnson, Z. B.; Sahlu, T.; Ferrell, C. L.; M. L. Galyean and Owens, F. N. 2004. Prediction of endogenous urinary nitrogen of goats. Small Ruminant Research 53:293-308.

Mahjoubi, E.; Amanlou, H.; Mirzaei-Alamouti, H. R.; Aghaziarati, N.; Yazdi, M. H.; Noori, G. R.; Yuan, K. and Baumgard, L. H.
2014. The effect of cyclical and mild heat stress on productivity and metabolism in Afshari lambs. Journal of Animal Science 92:1007-1014.

Noftsger, S.; St-Pierre, N. R. and Sylvester, J. T. 2005. Determination of rumen degradability and ruminal effects of three sources of methionine in lactating cows. Journal of Dairy Science 88:223-237.

NRC - National Research Council. Nutrient requirements of small ruminants: sheep, goats, cervids, and New World camelids. 2007. 1 st rev. ed. National Academy Press, Washington, DC.

O’Brien, M. D.; Rhoads, R. P.; Sanders, S. R.; Duff, G. C. and Baumgard, L. H. 2010. Metabolic adaptations to heat stress in growing cattle. Domestic Animal Endocrinology 38:86-94.

Obara, Y. and Shimbayashi, K. 1980. The appearance of re-cycled urea in the digestive tract of goats during the final third of a once daily feeding of a low-protein ration. British Journal of Nutrition 44:295-305

Obitsu, T.; Kamiya, M.; Kamiya, Y.; Tanaka, M.; Sugino, T. and Taniguchi, K. 2011. Effects of high ambient temperature on ureanitrogen recycling in lactating dairy cows. Animal Science Journal 82:531-536.

Robinson, T. F.; Sponheimer, M.; Roeder, B. L.; Passey, B.; Cerling, T. E.; Dearing, M. D. and Ehleringer, J. R. 2006. Digestibility and nitrogen retention in llamas and goats fed alfalfa, $\mathrm{C}_{3}$ grass, and $\mathrm{C}_{4}$ grass hays. Small Ruminant Research 64:162-168.

Tamminga, S.; Schulze, H.; Van Bruchem, J. and Huisman, J. 1995. The nutritional significance of endogenous n-losses along the gastrointestinal tract of farm animals. Archives of Animal Nutrition 48:9-22.

Waterlow, J. C. 1999. The mysteries of nitrogen balance. Nutrition Research Reviews 12:25-54. 